ulating or form regulating substance in neurosecretory granules, which is intimately involved in growth and regeneration. This view is based in part on the effect of neuropharmacological agents on regeneration, which I would regard as remarkably unimpressive and inconclusive. The most useful material in the book is the electron microscope observations, which provide a convenient and detailed structural description; the summarizing diagrams are particularly clear. There are also some interesting suggestions and observations on the control of nematocyst discharge.

For the research worker dealing with hydra this is quite a useful but uninspiring book. It cannot be recommended for other biologists. The many cell biology problems posed by hydra remain largely unexplored and even the problems of form, growth, regeneration, behaviour, communication and osmoregulation are undefined. If one is to write a book on a topic of considerable interest based mainly on one's own research work, then this work ought to be seminal, or at least well above average. The work described here is not.

L. WOLPERT

\section{TRACKING BRITISH MAMMALS}

\section{Mammals of Britain}

Their Tracks, Trails and Signs. By M. J. Lawrence and R. W. Brown. Pp. $223+32$ plates. (London: Blandford Press, 1967.) 30s. net.

Appearing so soon after the Handbook of British Mammals, a new book on the subject calls for some justification by way of fresh information and novel treatment. This useful book passes the test by reason of its concentration on drawings of the footprints and droppings of mammals and inclusion of many more drawings of skulls and teeth. The basic information about each species being less than is given in the Handbook, one still inevitably turns to the latter as a reference book, but Lawrence and Brown have produced a handy companion to the larger work. Another different feature is the distribution maps given for some (but not all) of the wild species (domestic animals are also included). These, I feel, do not always come off; some of them, such as otter, pine marten, Leisler's bat and mole, merely illustrate how very difficult it is to put imperfect information into map form. The authors are not, of course, to blame for the imperfection of the information, which is the fault of all British mammalogists, but they have tended to give an impression of precision where vagueness should have been the order of the day. And an attempt to show vagueness on a map usually ends in disaster.

I am also struck by how hard it is nowadays to produce a really up to date book on British wildlife. New facts are constantly emerging or being discovered, and no book can be completely up to date, even given perfect distribution of new knowledge. In this book, for instance, one naturally looks first to the mink, the grey long-eared bat and the coypu, and in each case events have moved on since the book was written, doubtless 18 months or so before it was published. But by the same token the authors are that much more up to date than the Handbook, published in 1964.

R. S. R. FitTer

\section{OBITUARIES}

\section{Sir Cyril Hinshelwood}

Sir Cyril Hinshelwood died at his London home during the evening of October 9. A few hours earlier he had talked with one research student and had written to another to arrange a discussion about a joint publication. His death came as a shock to his many friends who had seen him so relaxed and happy during recent years when, free from administrative duties, he was able to enjoy his laboratory work and pursue his many other interests.

Hinshelwood was recognized internationally as one of the finest intellects of our time, a polymath, a descendant of those men described in John Evelyn's diary as 'My lords virtuosi" - the early Fellows of the newly born Royal Society, over which he was to preside with distinction. Born in 1897, he was educated at Westminster City School, went to Balliol College, Oxford, in 1919 with a Brackenbury scholarship, and gained distinction in the shortened post-war course in 1920. After a year as a fellow of Balliol, he became a fellow and tutor of Trinity, and in 1937 succeeded Professor F. Soddy as Dr Lee's professor of physical and inorganic chemistry. On retirement in 1964, he returned to his native London as a senior research fellow of Imperial College. During his professorship, physical chemistry at Oxford reached full bloom. The move was made from the cellars and outhouses of Trinity and Balliol to new laboratories, and among his staff were nine Fellows of the Royal Society leading research groups in diverse fields.

From 1916-19 he worked at the Queensferry Royal Ordnance factory on explosives, where his remarkable ability was quickly noticed. This work stimulated his interest in the mechanisms of chemical change, which was to be the main theme of nearly all his scientific research. Throughout, he showed a mastery in planning simple measurements to answer questions of great complexity. His earliest papers dealt with the velocity of decomposition of solid substances and of reactions of gases on metallic catalysts. He soon turned to homogeneous gas reactions with special reference to theories of molecular activation. In 1926 he interpreted some first order decompositions of organic molecules as quasi-unimolecular processes involving activation by collisional mechanisms. Soon afterwards, from kinetic measurements he estab. lished the main characteristics of thermal chain reactions. The discovery of critical explosion limits, similar to those found by Semenov in other systems at about the same time, led to new ideas about straight and branching chains. The effects of catalysts such as iodine on some of these gas reactions, of inhibitors such as nitric oxide or propylene, and of deuterium were used to clarify other details. In those early years, the origin and nature of the chain carriers were obscure, and Hinshelwood sought, with meticulous care, to establish their identity. His final account of the hydrogen-oxygen reaction, given in the Bakerian lecture (1946), was the culmination of a long exemplary application of the scientific method to disentangle the intricacies of this process. Later, he studied the mechanism of thermal decomposition of hydrocarbons, and the polymerization of some unsaturated compounds. Over many years, too, he examined the kinetics of a variety of reactions in non-aqueous solvents and in the liquid phase. Here again, the main aim was to establish the significance of the constants in the Arrhenius equation and the functional relationships between them. He analysed the different approach in his own work and that of others using the so-called transition state theory, but emphasized clearly the fundamental relationships between the different methods. His book on The Kinetics of Chemical Change appeared, in a kind of evolutionary way, in four editions between 1926 and 1940 .

In 1938 he used the kinetic approach to study physicochemical aspects of bacterial growth, and this subject perhaps remained his major love to the end. The influence of added substances on the different phases of the growth curve, the adaptation of bacteria and their resistance to drug action caused by changes of media, the take-up of alkali metals or of phosphorus and the effect of different carbon sources, were examined. The living cell was con- 
ceived as a complex assemblage of chemical reactions, each subject to the same laws. "One of the sources of the richness and subtlety shown by the behaviour of living matter," he wrote, "is the way in which, in the individual, physico-chemical laws can play variations on the fundamental theme expressed by the genetic code, while populations can also respond in another way to rarer and more catastrophic changes in the code itself." $\mathrm{He}$ discussed these laws in many papers and in two books, The Chemical Kinetics of the Bacterial Cell (1946) and (with A. C. R. Dean) Growth, Function and Regulation in Bacterial Cells (1966). The question of cellular regulation was a recurring theme which found expression in what he called "the principle of total integration" and the "network theorem". These expressed in mathematical terms the mutual interdependence of all the components in the intact functioning cell. He had been asked for a non-mathematical presentation. Two days before his death, he wrote of his intention to do this, "pointing out where, which is in most places, the model is not in conflict with other descriptions, but adds something of its own". He was not unaware that his incursions into biology had encountered some scepticism among a few of the more traditional professional biologists. In his elegant book The Structure of Physical Chemistry (1951) he presented a unified, coherent story in his own eritically philosophic way. His first book, Thermodynamics for Students of Chemistry (1926), is another, less known, classic.

Hinshelwood was in turn president of the Chemical Society, Faraday Society, Royal Society, the British Association, and of the Classical Association; chairman of the Research Committee of the Gas Council, a delegate of the Clarendon Press, chairman of the Council of Queen Elizabeth College, London, a trustee of the British Museum, and on the court of the Goldsmiths Company. $\mathrm{He}$ served on many governmental advisory committees. His honours included the Davy, Royal, Copley and Leverhulme medals of the Royal Society, the Longstaff and Faraday medals of the Chemical Society, the Nobel Prize for Chemistry (shared with Semenov) and many medals given by foreign organizations. He received honorary doctorates from about a dozen universities, was a member of many foreign academies, and an honorary fellow of four Oxford colleges. In 1960 he received the Order of Merit.

To his fluency in numerous European languages there was added a competence in Russian and Chinese, with a little Arabic. He had a wide knowledge of English and foreign literature, of operatic music, of Chinese porcelain and Persian carpets, and was an accomplished painter in oils. He often contributed papers to the Oxford Dante Society. He was regarded with affection and respect by his colleagues, and by undergraduates in both the sciences and the humanities. In all his lectures and writings there was an unmistakable mark of the natural philosopher. None was more fitted than "Hinsh" to drink the tradi. tional toast of the Royal Society's dining club: "Arts and Sciences".

H. W. T.

\section{Dr Pierre Jacquet}

Pierre Jacquet and his wife died tragically at sea near Puerto de la Selva, Spain, during a trip in their cabin cruiser on September 6, 1967. Jacquet was born in 1906 at Saint-Mande (Seine), graduated as a chemical engineer from the Institut de Chimie, Paris, in 1926, and obtained his doctorate in 1938. He was well known throughout the world as the father of electropolishing, a phenomenon which he discovered in association with $\mathrm{H}$. Figour in 1929.

$\mathrm{He}$ first described this process in the Comptes Rendus in $1935(201,1473)$, and spent the rest of his scientific life investigating fundamental aspects of the phenomenon, applying it to a wide range of metals and alloys, and encouraging its industrial application. This work is recorded in more than 200 papers published in manyjournals in France and elsewhere. It is no exaggeration to say that electrolytic polishing has revolutionized not only the practice of metallography by providing the most scientific way of preparing polished surfaces free from strain and blemishes, but also methods of surface preparation in industry where it is now extensively used for polishing and machining. In addition, the present techniques of electron microscopy of metals and alloys are almost entirely dependent on methods pioneered by Jacquet. In recent years Jacquet developed the technique further so that it could be used in situ on larger structures or objects, thus initiating a new approach in non-destruc. tive metallography. A detailed list of the fields in which Jacquet has made effective contributions would include most of the important aspects of physical metallurgy. Much of his early work was done in the Research Labor. atory of the Société, le Materiel Téléphonique, but since 1945 he worked in the Research Laboratory of the French Navy, from which he had only recently retired.

His scientific work has been recognized by many awards including the Berthelot Medal (1956), the Jaffe Prize of the French Academy, and the Le Chatelier Medal of the Société Française de Métallurgie. He was a Chevalier de la Légion d'Honneur and an Honorary Foreign Member of the American Academy of Arts and Seiences (1956).

Jaequet will be long remembered as a modest, retiring man who by firm conviction and a long scientific career at the laboratory bench made outstanding contributions to metallurgical science and technology.

\section{R. W. K. Honeycombe}

\section{Dr Francis Silsbee}

Francis Briggs Silsbee, who died on August 21, aged 78, retired as Chief of the Electricity Division of the US National Bureau of Standards in 1959. He had made many contributions to electrical engineering.

Silsbee graduated in electrical engineering from the Massachusetts Institute of Technology in 1910 and obtained a master's degreo the following year. In 1915 he obtained his doctorate from Harvard University. He joined the National Bureau of Standards in 1911, and continued to act as a consultant after his retirement, when he was interested in the history of the scientific work of the bureau. He was chairman of a committee whose work led to the establishment of the NBS Museum, which exhibits instruments made during the 66 years of the bureau's existence.

Silsbee's contributions to electrical engineering included involvement in the design of alternating current resistors of exceptionally low reactance. He also invented the test set which is used by industry to compare working current transformers with standard transformers of known ratio and phase angle. During the Second World War, he investigated lighting hazards to aireraft for the National Advisory Committee of Aeronautics. As chief of the Electricity Division at the National Bureau of Standards he was concerned with ostablishing electrical units and standards, and took part in committee work with the International Electrotechnical Commission and other standardizing organizations. In 1956 Silsbee was sent to Ethiopia by the International Co-operation Commission to advise the government on the establishment of a national system of measurement standards.

Silsbee was a fellow of the Institute of Electrical and Electronics Engineers, a fellow of the American Physical Society, and a former president of the Washington Philosophical Society and the Washington Academy of Sciences. In 1963 he received the Morris E. Leeds Award for his contribution to the methods of improving the accuracy of commercial electrical measurements. He also received Exceptional Service Awards from the Department of Commerce and the Naval Bureau of Ordinance. 